\title{
Prevalence and Associated Factors of HIV Testing Among Pregnant Women: A Multilevel Analysis Using the Recent Demographic and Health Survey Data from II East African Countries
}

This article was published in the following Dove Press journal:

HIVIAIDS - Research and Palliative Care

\author{
Misganaw Gebrie Worku (D) \\ Achamyeleh Birhanu Teshale (iD) ${ }^{2}$ \\ Getayeneh Antehunegn Tesema (iD) ${ }^{2}$ \\ 'Department of Human Anatomy, \\ University of Gondar, College of \\ Medicine and Health Science, School of \\ Medicine, Gondar, Ethiopia; ${ }^{2}$ Department \\ of Epidemiology and Biostatistics, \\ Institute of Public Health, College of \\ Medicine and Health Sciences, University \\ of Gondar, Gondar, Ethiopia
}

\begin{abstract}
Aim: In developing countries, particularly in sub-Saharan Africa, the burden of mother to child transmission (MTCT) of HIV is higher. Although the Joint United Nations Programme on HIV/AIDS (UNAIDS) and other organizations are working to eliminate MTCT, a large number of pregnant women are not screened for HIV in most African countries.

Methods: The demographic health survey (DHS) used two-stage stratified sampling technique to select the study participants and we appended the most recent DHS done in the 11 East African countries. A weighted sample of 53, 420 women were included. A multilevel logistic regression analysis was used due to the hierarchical structure of the DHS data. To determine whether or not there was a clustering, the Interclass Correlation Coefficient (ICC) and Median Odds Ratio (MOR) were determined. Model comparison was conducted using deviance (-2LL).

Results: The prevalence of HIV testing among pregnant women was $77.56 \%[95 \% \mathrm{CI}=$ $77.20 \%, 77.91 \%$ ]. In the Multivariable multi-level analysis, variables such as respondent age, wealth index, marital status, educational level, HIV knowledge, HIV stigma indicator, risky sexual activity, women visiting health care facilities, multiple sexual partnership, early sexual initiation, and awareness about MTCT were the individual-level factors that were associated with HIV testing among pregnant women. While residence and community-level education were the community-level factors that were significantly associated with HIV testing.

Conclusion: The prevalence of HIV testing and counseling among pregnant women was higher compared to the previous report. Respondent age, wealth index, marital status, educational level, HIV knowledge, HIV stigma indicator, risky sexual activity, women visiting health care facilities, multiple sexual partnership, early sexual initiation, residence, community-level education and awareness about MTCT were the significant determinant of HIV testing.
\end{abstract}

Keywords: HIV/AIDS, East Africa, pregnant women, multilevel analysis

\section{Background}

Globally, in 2015, an average of 1.8 million children under the age of 15 years were living with HIV with children living in Sub-Saharan Africa accounts for the majority of the infection. Despite continuing progress in preventing new HIV infections among children, there are still major challenges in ensuring access to appropriate antiretroviral therapy for children living with HIV. The challenges start with HIV diagnosis among
Worku

Department of Human Anatomy,

University of Gondar, College of Medicine and Health Science, School of Medicine,

PO. Box: 196, Gondar, Ethiopia

$\mathrm{Tel}+251925987029$

Email misgeb2008@gmail.com 
children. ${ }^{1}$ Although UNAIDS and other organizations are working to eradicate mother-to-child transmission (MTCT) of HIV, only less than $90 \%$ of pregnant women are screened for HIV in most African countries. ${ }^{2}$

More than $90 \%$ of infections among children infected with the virus occur through $\mathrm{MTCT}^{3}$ and low HIV test uptake has been considered as a bottleneck for the prevention of mother to child transition (PMTCT). ${ }^{4}$ HIV infection control depends on the efficacy of new infection prevention approaches and the treatment of people who are already infected. ${ }^{5}$ In developing countries MTCT of HIV varies from $25 \%$ to $48 \%$, which is greater than the report in developed countries. ${ }^{6}$ One of the key preventive measures for MTCT is HIV screening of all women of childbearing age. ${ }^{7}$ However, a large number of women are not yet tested for HIV/AIDS. ${ }^{8}$ HIV/AIDS poses a significant public health burden worldwide. ${ }^{9}$ HIV testing and counseling services in sub-Saharan Africa is low. ${ }^{9}$ According to the Joint United Nations Programme, more than 180000 children were newly infected with HIV in 2017 and mostly through MTCT. ${ }^{10,11}$

In addition to reducing morbidity and mortality among infected people, early detection of HIV infection is recognized as a critical component of disease spread control. ${ }^{12,13}$ Several studies indicate that many infected individuals control their behaviors, such as unprotected sex or needlesharing, that likely transmit the infection to their partners once they are aware of their positive HIV status. ${ }^{14,15}$

According to different literatures, education level, marital status, place of residence, location, wealth, knowledge of MTCT during pregnancy and having a stigmatizing attitude, knowledge of HIV/AIDS, having risky sexual activity are factors that affect HIV testing among pregnant women. ${ }^{16-19}$

While HIV testing is a priority for all pregnant women, many women are not screened for HIV during pregnancy. ${ }^{7,17}$ Insufficient resources, stigma, the attitudes and skills of health workers, and HIV testing strategy are considered to be the key reasons for low HIV testing during pregnancy in sub-Saharan African countries, particularly in eastern Africa. ${ }^{20}$ So this study aimed to assess the prevalence of HIV testing and associated factor among pregnant women in eastern Africa.

\section{Methods}

\section{Data Sources}

A secondary data analysis using the pooled data from the most recent Demographic and Health Surveys (DHS) of the 11 East African countries was done. The DHS used a stratified two-stage sampling technique to select the study participants. We used the women's datasets (individual record file) for this analysis and we included only women who gave birth in the past one year before each survey. Finally, a total weighted sample of 53, 420 women was included for this study. The survey year and the weighted sample taken from each country indicated in Table 1 .

\section{Variables of the Study Outcome Variable}

The outcome variable is the uptake of HIV testing during pregnancy (a binary outcome variable coded as yes or no).

\section{Independent Variables}

Maternal age, marital status (categorized as never married, married and divorced/widowed/separated), educational status (no education, primary, secondary and higher), wealth index (poorest, poorer, middle, richer and richest), knowledge about HIV/AIDS, having stigma attitude towards people with HIV, risky sexual behavior, age at first sex, multiple sexual partnership, visiting health facility, awareness of MTCT of HIV/AIDS and employment status were the individual level factor included in this study. While community-level education and residency were the community-level factors.

\section{Operational Definitions}

Awareness of MTCT of HIV was defined as awareness of women about the possibility of HIV transmission from HIV positive mother to her child, which is

Table I The Survey Year and Total Weighted Sample for Each Country

\begin{tabular}{|l|l|l|}
\hline Country & Year of Survey & Weighted Sample \\
\hline Burundi & 2016 & 2987 \\
Ethiopia & 2016 & 5088 \\
Kenya & 2014 & 7967 \\
Comoros & 2012 & 1487 \\
Madagascar & 2008 & 5498 \\
Malawi & $2015 / 16$ & 7519 \\
Mozambique & 2011 & 5455 \\
Rwanda & 2352 & 3589 \\
Uganda & 2016 & 6845 \\
Zambia & 2018 & 4335 \\
Zimbabwe & $2013 / 2014$ & 2651 \\
\hline Total & & 53,420 \\
\hline
\end{tabular}


generated from three questions knowledge about HIV transmission during breast feeding, during delivery, and pregnancy.

Respondent's knowledge about HIV/AIDS was created based on six questions: three questions on HIV prevention information and three questions on misconceptions of HIV transmission modes and it was graded as low (score 3), high (score 4-5), or comprehensive (score 6) knowledge.

Having had any sexually transmitted disease, genital sore/ulcer, genital discharge, having at least one sexual partner other than the husband in the last twelve months and multiple lifetime sexual partnership were the five questions asked to determine participants' risky sexual activities. These were combined into an index of having risky sexual behavior with three categories: "no risk" (score 0), "some risk" (score 1) and "high risk" (score $\geq 2$ ).

More over, six questions reflecting negative attitudes towards people living with HIV/AIDS were used to create a stigma index. This index was graded "no stigma" (score 6), "low stigma" (score 4-5), "moderate stigma" (score 2-3) and "high stigma" (score 1). ${ }^{21}$

\section{Data Management and Analysis}

Before any statistical analysis, the data were weighted to restore the representativeness of the data and to achieve an accurate estimate and standard error. STATA version 14 software was used to extract, recode, and analyze data. A multilevel logistic regression analysis was used due to the hierarchical structure of the DHS data, which violates the independent assumptions of the standard logistic regression model. Four models were incorporated; the null model-a model without explanatory variables, model I-a model with individual-level variables, model II-a model with community-level variables, and model III-a model with individual and community-level variables. The Interclass Correlation Coefficient (ICC) and Median Odds Ratio (MOR) were calculated to determine whether clustering was occurred or not. Deviance $(-2 L L)$ and percentage change in variation (PCV) were used to compare models. Among these models, Model III was selected as the best-fit model because it had the lowest deviance. Both bivariable and multivariate multi-level logistic regression were performed. Variables with a p-value of less than 0.2 were considered for multivariable analysis. In the multivariable analysis Variables with a P-value, lower than 0.05 were considered as the statistically significant factors associated with HIV testing among pregnant women.

\section{Results \\ Socio-Demographic Characteristics of Study Participants}

A total of 53,420 reproductive-age women who gave birth in the past one year preceding each survey were included. Around $28 \%$ of the study participants were in the age of 20-24 years and more than half (52.61\%) of the study participants had primary education. About $46.11 \%$ of women were from poor households and more than half (59.67\%) of the study participants initiate sex before 20 years of age. Nearly $49 \%$ of the study participants had comprehensive knowledge about HIV/AIDS and the majority (85.28\%) of the study participants were married. Regarding attitude towards people with HIV/AIDS, more than $95 \%$ of the study participant had a negative attitude toward people with HIV. Looking at risky sexual behavior, about $59.67 \%$ of the study participants had some risky sexual behavior (Table 2).

\section{Prevalence of HIV Testing Among Pregnant Women in Eastern Africa}

The prevalence of HIV testing among pregnant women in eastern Africa was 77.56\%[95\% CI=77.20\%, 77.91\%], which ranges from $8.96 \%$ in Madagascar to $99.66 \%$ in Rwanda (Figure 1).

\section{Random Effect Model and Model Fitness}

ICC, MOR and PCV were used to assess the random-effect model. The ICC value of 0.27 in the null model shows that $27 \%$ of the overall variation in HIV testing among pregnant women was due to variations between clusters/communities. Besides, the highest MOR value of 2.72 suggests that substantial clustering of HIV testing among pregnant women has occurred. Also, the highest PCV (0.35) in the final model showed that both the individual and community-level variables explained about $35 \%$ of the variation in HIV testing. The final model (model III), which incorporates both individual and community level variables, was the best fitted model since it had the lowest deviance (Table 3). 
Table 2 Sociodemographic Characteristics of the Respondents in Eastern Africa $(\mathrm{N}=53,420)$

\begin{tabular}{|c|c|c|}
\hline \multicolumn{2}{|l|}{ Variables } & \multirow{2}{*}{$\begin{array}{l}\text { Frequency (\%) } \\
7278(13.62 \%) \\
14,750(27.60 \%) \\
13,170(24.64 \%) \\
9592(17.95 \%) \\
8660(16.20 \%)\end{array}$} \\
\hline Age (years) & $\begin{array}{l}15-19 \\
20-24 \\
25-29 \\
30-34 \\
35 \text { and above }\end{array}$ & \\
\hline $\begin{array}{l}\text { Highest } \\
\text { education level }\end{array}$ & $\begin{array}{l}\text { No education } \\
\text { Primary education } \\
\text { Secondary education } \\
\text { Higher education }\end{array}$ & $\begin{array}{l}I I, 839(22.15 \%) \\
28,123(52.61 \%) \\
I I, 45 \mid(21.42 \%) \\
2039(3.81 \%)\end{array}$ \\
\hline Wealth index & $\begin{array}{l}\text { Poor } \\
\text { Middle } \\
\text { Rich }\end{array}$ & $\begin{array}{l}24,647(46.1 \mid \%) \\
\mid 0,274(19.22 \%) \\
|8,53|(34.67 \%)\end{array}$ \\
\hline $\begin{array}{l}\text { Risky sexual } \\
\text { behavior }\end{array}$ & $\begin{array}{l}\text { No risk } \\
\text { Some risk } \\
\text { High risk }\end{array}$ & $\begin{array}{l}16,892(31.60 \%) \\
31,897(59.67 \%) \\
4662(8.72 \%)\end{array}$ \\
\hline $\begin{array}{l}\text { HIV } \\
\text { knowledge }\end{array}$ & $\begin{array}{l}\text { Low knowledge } \\
\text { High knowledge } \\
\text { Comprehensive knowledge }\end{array}$ & $\begin{array}{l}6049(\mathrm{II} .32 \%) \\
26, \mathrm{II} 2(48.85 \%) \\
21,29 \mathrm{I}(39.83 \%)\end{array}$ \\
\hline Marital status & $\begin{array}{l}\text { Never married } \\
\text { Married/live with partner } \\
\text { Widowed/divorced/separated }\end{array}$ & $\begin{array}{l}3736(6.99 \%) \\
45,585(85.28 \%) \\
4131(7.73 \%)\end{array}$ \\
\hline Working status & $\begin{array}{l}\text { Not employed } \\
\text { Employed }\end{array}$ & $\begin{array}{l}24,907(46.60 \%) \\
28,545(53.40 \%)\end{array}$ \\
\hline $\begin{array}{l}\text { Multiple sexual } \\
\text { partner }\end{array}$ & $\begin{array}{l}\text { No } \\
\text { Yes }\end{array}$ & $\begin{array}{l}26,168(48.96 \%) \\
27,283(51.04 \%)\end{array}$ \\
\hline $\begin{array}{l}\text { Stigma } \\
\text { indicator }\end{array}$ & $\begin{array}{l}\text { No stigma } \\
\text { Low stigma } \\
\text { Moderate stigma } \\
\text { High stigma }\end{array}$ & $\begin{array}{l}205 \mid(3.84 \%) \\
\mid I, 065(20.70 \%) \\
22,784(42.63 \%) \\
|7,55|(32.84 \%)\end{array}$ \\
\hline Residence & $\begin{array}{l}\text { Urban } \\
\text { Rural }\end{array}$ & $\begin{array}{l}11,534(21.58 \%) \\
41,917(78.42 \%)\end{array}$ \\
\hline $\begin{array}{l}\text { Awareness } \\
\text { about MTCT }\end{array}$ & $\begin{array}{l}\text { No } \\
\text { Yes }\end{array}$ & $\begin{array}{l}1839(3.44 \%) \\
51,612(96.56 \%)\end{array}$ \\
\hline Age at sex & $\begin{array}{l}\text { Before } 20 \text { years } \\
\text { At } 20 \text { and after years }\end{array}$ & $\begin{array}{l}40,597(75.95 \%) \\
12,855(24.05 \%)\end{array}$ \\
\hline $\begin{array}{l}\text { Visit health } \\
\text { facility }\end{array}$ & $\begin{array}{l}\text { No } \\
\text { Yes }\end{array}$ & $\begin{array}{l}17,039(31.88 \%) \\
36,413(68.12 \%)\end{array}$ \\
\hline $\begin{array}{l}\text { Community- } \\
\text { level education }\end{array}$ & $\begin{array}{l}\text { High level of education } \\
\text { Low level of education }\end{array}$ & $\begin{array}{l}25,529(47.76 \%) \\
27,922(52.24 \%)\end{array}$ \\
\hline
\end{tabular}

\section{Factors Associated with HIV Testing Among Pregnant Women in Eastern Africa}

We consider the final model for determining factors associated with HIV testing since it had the lowest deviance. In the multivariable multi-level analysis variables such as respondent age, residence, wealth index, marital status, educational level, HIV knowledge, HIV stigma indicator, risky sexual activity, women visiting health care facilities, multiple sexual partnership, early sex initiation, awareness about MTCT and community level of education were significantly associated with HIV testing among pregnant women. Pregnant women who were aged between 20 and 24 [AOR=1.51: 95\% CI: 1.37, 1.65], 25-29 [AOR=1.52: 95\% CI; 1.37, 1.68], 30-34 [AOR=1.58: 95\% CI; 1.42, 1.76], and 35 and above years $(\mathrm{AOR}=1.45: 95 \% \mathrm{CI} ; 1.30,1.61)$ had higher odds of being tested for HIV compared with women aged 15-19 years of age. Pregnant women who had visited a health facility in the last 12 months had $2.56(\mathrm{AOR}=2.56$ : $95 \%$ CI; 2.40, 2.72) times higher odds of being tested for HIV. Regarding educational status, the chances of HIV testing were $2.57(\mathrm{AOR}=2.57 ; 95 \% \mathrm{CI} ; 2.40,2.75), 2.47$ $(\mathrm{AOR}=2.47 ; 95 \% \mathrm{CI} ; 2.15,2.62)$ and $3.77(\mathrm{AOR}=3.77$; $95 \% \mathrm{CI} ; 2.94,4.83$ ) times higher for women with primary, secondary and higher education, respectively, compared to women without formal education. Considering household wealth status, women from the rich household $(\mathrm{AOR}=1.17$ : $95 \%$ CI; 1.08, 1.27) had higher chances of being tested for HIV compared with women from poor households. Widowed/divorced/separated women had a $38 \%$ ( $\mathrm{AOR}=0.62: 95 \% \mathrm{CI} ; 0.53,0.74)$ lower chance of being tested for HIV compared with never-married women. A woman who had no sexual partner other than her husband was less likely to be tested for HIV (AOR $=0.20: 95 \% \mathrm{CI}$; $0.18,0.22)$. Women who had initiated sex at an older age had 1.49 (AOR=1.49: 95\% CI; 1.38, 1.60) times higher odds of being tested for HIV compared with those who initiate sex at an early age. Being rural dweller had 39\% (AOR $=0.61: 95 \% \mathrm{CI} ; 0.56,0.67)$ lower chances of being tested for HIV/AIDS compared with their counterparts. Regarding stigma attitude, there were $9.55 \quad(\mathrm{AOR}=9.55$ : 95\% CI; 8.92, 10.22), 21.91 (AOR=21.91: 95\% CI; 19.79, 24.26) and 26.07 (AOR=26.07: 95\% CI; 20.62, 32.97) times 


\section{Prevalence of HIV testing among pregnant women in eastern Africa}

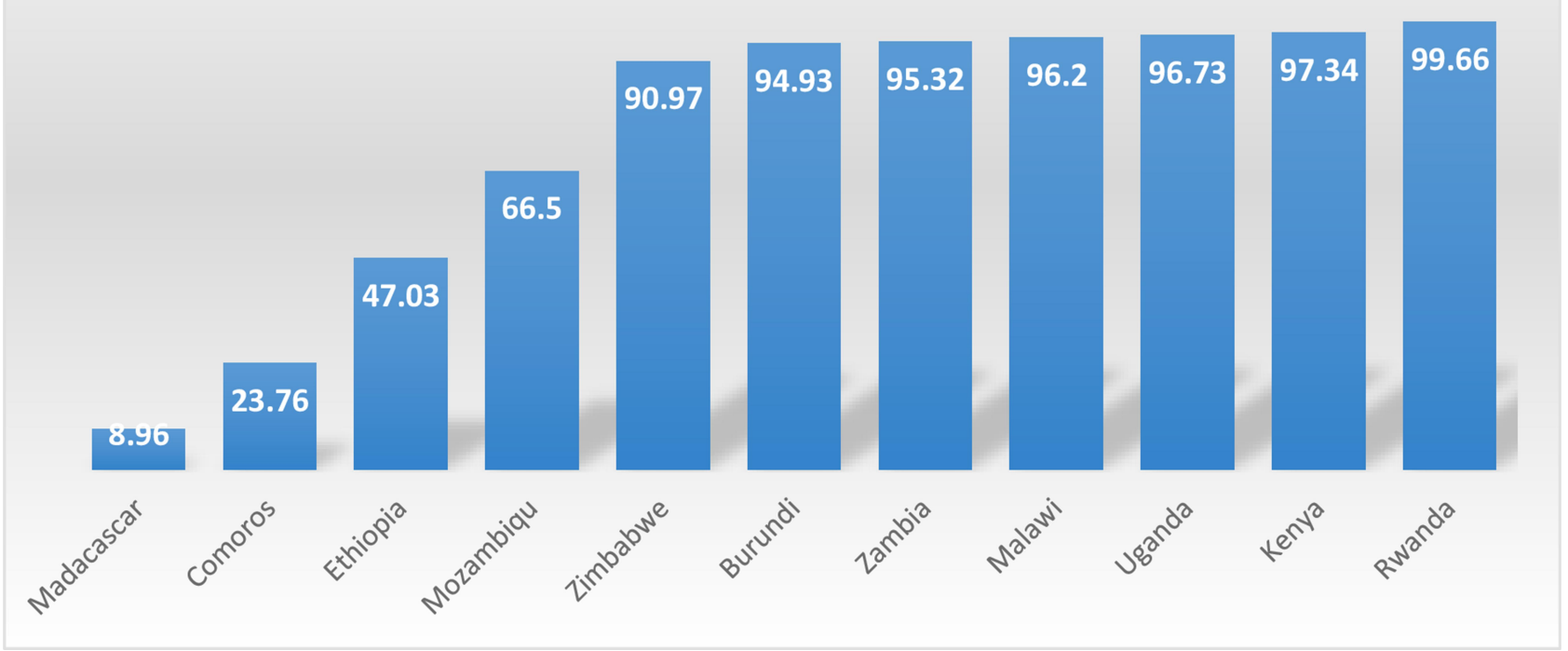

Figure I The prevalence of HIV testing among pregnant women in eastern Africa.

higher chances of being tested for HIV testing for women with moderate, low stigma score and those with no stigmatized attitude, respectively, compared to women with higher stigmatized attitude. Importantly, women with higher $(\mathrm{AOR}=1.09: 95 \% \mathrm{CI} ; 1.01,1.18)$ and comprehensive $(\mathrm{AOR}=3.31: 95 \% \mathrm{CI} ; 3.01,3.65)$ knowledge about HIV/ AIDS were more likely to be tested for HIV compared to those with low knowledge. Women with risky sexual behavior were more likely to be tested for HIV compared to women with no risky sexual behavior. Women who were aware of MTCT of HIV/AIDS were more likely to be tested for HIV/AIDS (AOR=1.29: 95\% CI; 1.12, 1.48). Pregnant women from communities with higher community level of education had $1.88(\mathrm{AOR}=1.88: 95 \% \mathrm{CI} ; 1.58,2.25)$ times higher odds of being tested for HIV/AIDS compared with those from communities with lower community level of education. Regarding employment status, employed women had a lower chance of being tested for HIV/AIDS compared with unemployed women $(\mathrm{AOR}=0.78$ : $95 \% \mathrm{CI}$; 0.74, 0.83) (Table 4).

\section{Discussion}

HIV testing during pregnancy provides an opportunity for the prevention of mother-to-child transmission and to initiate lifelong antiretroviral treatment for HIV-positive women before the disease progress to AIDS. This study showed that $77.56 \%[95 \% \mathrm{CI}=77.20 \%, 77.91 \%]$ of women who gave birth in the past one year before each survey got HIV test. It was greater than studies done in Ethiopia, ${ }^{16}$ Nigeria, ${ }^{22}$ and Gambia. ${ }^{23}$ This finding was smaller than the prevalence of HIV testing reported in Spain ${ }^{24}$ and Malawi. $^{2}$ The discrepancy might be due to the difference in the study period, the study population, and the availability and accessibility of maternal health services between countries.

In the multi-level multivariate analysis, age of respondent, educational level, household wealth status, visiting health facility, residence, age at sex, occupational status, knowledge about HIV/AIDS, stigmatized attitude about people with HIV/AIDS, risky sexual behavior, having awareness about MTCT, having multiple sexual partners, marital status and community-level of women education were significantly associated with HIV testing among pregnant women in eastern Africa. Being older had higher odds of testing for HIV compared with young aged women. This finding is supported by a study conducted in Malawi. ${ }^{2}$ This may be attributable to young individuals might have a low engagement of sexual behaviors, 
Table 3 Random Effect Model and Model Fitness for the Assessment of HIV Testing Among Pregnant Women in Eastern Africa

\begin{tabular}{|l|l|l|l|l|}
\hline Parameter & Null Model & Model I & Model II & Model III \\
\hline ICC & 0.27 & 0.33 & 0.23 & 0.33 \\
PCV & Reff & 0.32 & 0.17 & 0.35 \\
MOR & 2.72 & 5.57 & 2.61 & 3.4 \\
\hline Model comparison & & & \\
\hline Log likelihood & $-26,417.022$ & $-17,451.431$ & $-25,784.047$ & $-17,367.74$ \\
Deviance & $52,834.044$ & $34,902.862$ & $50,568.094$ & $34,735.48$ \\
\hline
\end{tabular}

therefore perceive themselves as having a lower risk of HIV, which in turn contributes to low uptake of HIV testing and counseling. ${ }^{2}$

In this study women with primary and higher education had higher odds of HIV testing compared with women without formal education, which is supported by studies conducted in Ethiopia ${ }^{21,25}$ and Spain. ${ }^{24}$ The reason for this is that education can improve HIV-related knowledge and improves income among women that in turn increases maternal health service use. ${ }^{25}$ Also, educated women might have higher levels of exposure to HIV/AIDSrelated information, better knowledge regarding the advantages of HIV testing, as well as ability to make good decisions to go for HIV testing. ${ }^{24}$

Women from rural resident had less chance of HIV testing compared with those of urban residents and this is supported by a previous study in Ethiopia. ${ }^{16}$ This might be justified as in most developing countries the health facilities were not accessible to the rural population and this decreases their chance of getting HIV counseling and testing. ${ }^{26}$ Pregnant women with some and higher risky sexual behavior had higher odds of being tested for HIV/ AIDS compared with women with no risky sexual behavior. This finding was supported by studies conducted elsewhere. ${ }^{18,21,27}$ Individuals with risky sexual behaviors live under persistent fear and uncertainty about their serostatus and are usually suspicious and worried that they might have infected with HIV, this could have urged them to develop habits of seeking voluntary counseling and testing service. ${ }^{28}$ Concerning HIV/AIDS knowledge, pregnant women having higher and comprehensive knowledge about HIV had higher chances of HIV testing compared to women with low knowledge. This finding was supported by different studies. ${ }^{18,21}$ This might be justified by people with a good understanding of HIV/AIDS including its transmission and preventive measures helps them to seek
HIV testing voluntarily. ${ }^{29}$ Looking at marital status, widowed/divorced/separated women had lower odds of being tested for HIV compared with unmarried women. This finding was supported by another study conducted in Ethiopia. ${ }^{21}$ This might be associated with those populations were less likely to visit the health facility and to have voluntary counseling and testing unlike those of married women. ${ }^{21}$ Regarding household wealth status, a woman in the high socioeconomic categories was more likely to be tested for HIV than women from poor household. This finding was consistent with other studies. ${ }^{16,29}$ This can be justified as women with higher socioeconomic status have a better educational level and are economically privileged to seek and access health services including voluntary counseling and testing services than those in the lower socioeconomic class. ${ }^{21}$

The study at hand also revealed that women who had visited a health facility in the past 12 months were more likely to be tested for HIV/AIDS, which was in agreement with the study done in Ethiopia. ${ }^{25}$ This might be as women who had visited the health facility were advised and supported by the health workers to have voluntary counseling and testing. ${ }^{25}$ Similarly, pregnant women having awareness about mother-to-child transmission of HIV had a higher chance of being tested for HIV/AIDS compared with their counterparts. This finding was supported by studies in Ethiopia. ${ }^{25,29}$

In this study women with multiple sexual partnership were more likely to be tested for HIV/AIDS compared with their counterparts. A similar finding was reported from a study in Ethiopia. ${ }^{25}$ This might be due to the fact that women with multiple sexual partnership had a higher perceived risk of acquiring HIV, which increases their motive to be tested. ${ }^{30}$

Moreover, women who had initiated sex after 20 years of age had higher odds of HIV testing compared with 
Table 4 The Bivariable and Multivariable Multilevel Binary Logistic Regression Analysis of Factors Associated with HIV Testing Among Pregnant Women in Eastern Africa

\begin{tabular}{|c|c|c|c|c|c|}
\hline \multicolumn{2}{|l|}{ Variables } & \multicolumn{2}{|c|}{ Ever Tested for HIV } & \multirow[t]{2}{*}{ COR(95\% Cl) } & \multirow[t]{2}{*}{ AOR(95\% CI) } \\
\hline & & No & Yes & & \\
\hline Respondent age & $\begin{array}{l}15-19 \\
20-24 \\
25-29 \\
30-34 \\
35 \text { and above }\end{array}$ & $\begin{array}{l}1922 \\
3000 \\
2761 \\
2140 \\
2165\end{array}$ & $\begin{array}{l}5356 \\
11,744 \\
10,402 \\
7435 \\
6495\end{array}$ & $\begin{array}{l}\text { I } \\
1.48(1.38,1.59) \\
1.41(1.31,1.51) \\
1.41(1.31,1.52) \\
I .19(1.10,1.29)\end{array}$ & $\begin{array}{l}\text { I } \\
1.5 \mathrm{I}(1.37,1.66)^{*} \\
1.52(1.37,1.68)^{*} \\
1.58(1.42,1.76)^{*} \\
1.45(1.30,1.61)^{*}\end{array}$ \\
\hline Visiting health facility & $\begin{array}{l}\text { No } \\
\text { Yes }\end{array}$ & $\begin{array}{l}5943 \\
6043\end{array}$ & $\begin{array}{l}11,074 \\
30,358\end{array}$ & $\begin{array}{l}\text { I } \\
3.53(3.36,3.70)\end{array}$ & $\begin{array}{l}\text { I } \\
2.56(2.40,2.72)^{*}\end{array}$ \\
\hline Highest educational level & $\begin{array}{l}\text { No education } \\
\text { Primary education } \\
\text { Secondary education } \\
\text { Higher education }\end{array}$ & $\begin{array}{l}5192 \\
5449 \\
1259 \\
88\end{array}$ & $\begin{array}{l}6633 \\
22,659 \\
10,189 \\
|95|\end{array}$ & $\begin{array}{l}\text { I } \\
3.59(3.40,3.78) \\
4.69(6.03,6.98) \\
15.36(12.48,18.91)\end{array}$ & $\begin{array}{l}\text { I } \\
2.57(2.40,2.75)^{*} \\
2.47(2.15,2.62)^{*} \\
3.77(2.94,4.83)^{*}\end{array}$ \\
\hline Wealth status & $\begin{array}{l}\text { Poor } \\
\text { Middle } \\
\text { Rich }\end{array}$ & $\begin{array}{l}6925 \\
2459 \\
2603\end{array}$ & $\begin{array}{l}17,699 \\
7811 \\
15,922\end{array}$ & $\begin{array}{l}\text { I } \\
\text { I.49(I.40, I.58) } \\
2.84(2.69 .3 .01)\end{array}$ & $\begin{array}{l}\text { I } \\
1.06(0.98,1.14)^{*} \\
1.17(1.08,1.27)^{*}\end{array}$ \\
\hline Marital status & $\begin{array}{l}\text { Never married } \\
\text { Married } \\
\text { Widowed/divorced/separated }\end{array}$ & $\begin{array}{l}385 \\
10,609 \\
994\end{array}$ & $\begin{array}{l}3351 \\
34,945 \\
3136\end{array}$ & $\begin{array}{l}I \\
0.45(0.4 I, 0.5 I) \\
0.4 I(0.36,0.47)\end{array}$ & $\begin{array}{l}\text { I } \\
0.92(0.80,1.06) \\
0.62(0.53,0.74)^{*}\end{array}$ \\
\hline Multiple sexual partner & $\begin{array}{l}\text { No } \\
\text { Yes }\end{array}$ & $\begin{array}{l}5340 \\
6648\end{array}$ & $\begin{array}{l}20,806 \\
20,625\end{array}$ & $\begin{array}{l}0.94(0.89,0.98) \\
I\end{array}$ & $\begin{array}{l}0.20(0.18,0.22)^{*} \\
\mathrm{I}\end{array}$ \\
\hline HIV knowledge & $\begin{array}{l}\text { Low knowledge } \\
\text { Higher knowledge } \\
\text { Comprehensive knowledge }\end{array}$ & $\begin{array}{l}2473 \\
7976 \\
1539\end{array}$ & $\begin{array}{l}357 \mid \\
18,122 \\
19,738\end{array}$ & $\begin{array}{l}\text { I } \\
\text { I.49(I.39. I.58) } \\
9.48(8.75,10.28)\end{array}$ & $\begin{array}{l}\text { I } \\
1.09(1.01,1.18)^{*} \\
3.31(3.01,3.65)^{*}\end{array}$ \\
\hline Stigma indicator & $\begin{array}{l}\text { Higher stigma } \\
\text { Moderate stigma } \\
\text { Low stigma } \\
\text { No stigma }\end{array}$ & $\begin{array}{l}84201 \\
2697 \\
809 \\
61\end{array}$ & $\begin{array}{l}9110 \\
20,075 \\
10,256 \\
1990\end{array}$ & $\begin{array}{l}\text { I } \\
\text { I2.22(II.5I, I2.98) } \\
26.09(23.76,28.64) \\
35.5 \mid(28.36,44.46)\end{array}$ & $\begin{array}{l}\text { I } \\
9.55(8.92,10.22)^{*} \\
21.91(19.79,24.26)^{*} \\
26.07(20.62,32.97)^{*}\end{array}$ \\
\hline Residence & $\begin{array}{l}\text { Urban } \\
\text { Rural }\end{array}$ & $\begin{array}{l}1108 \\
10,878\end{array}$ & $\begin{array}{l}10,418 \\
31,014\end{array}$ & $\begin{array}{l}\text { I } \\
0.36(0.34,0.39)\end{array}$ & $\begin{array}{l}\text { I } \\
0.6 \mathrm{I}(0.56,0.67)^{*}\end{array}$ \\
\hline Working statues & $\begin{array}{l}\text { Not employed } \\
\text { Employed }\end{array}$ & $\begin{array}{l}5392 \\
6595\end{array}$ & $\begin{array}{l}19,486 \\
21,946\end{array}$ & $\begin{array}{l}\text { I } \\
0.96(0.91,1.00)\end{array}$ & $\begin{array}{l}\text { I } \\
0.78(0.74,0.83)^{*}\end{array}$ \\
\hline Risky sexual behavior & $\begin{array}{l}\text { Higher risk } \\
\text { Some risk } \\
\text { No risk }\end{array}$ & $\begin{array}{l}525 \\
7149 \\
4313\end{array}$ & $\begin{array}{l}4137 \\
24,720 \\
12,575\end{array}$ & $\begin{array}{l}2.79(2.52,3.10) \\
1.19(1.13,1.24)\end{array}$ & $\begin{array}{l}8.66(7.37,10.17)^{*} \\
4.61(4.16,5.11)^{*} \\
1\end{array}$ \\
\hline Age at sex & $\begin{array}{l}\text { Before } 20 \text { years } \\
\text { At } 20 \text { and above years }\end{array}$ & $\begin{array}{l}9498 \\
2489\end{array}$ & $\begin{array}{l}31,085 \\
10,347\end{array}$ & I $1.32(1.25,1.39)$ & $1.49(1.38,1.60)^{*}$ \\
\hline Awareness of MTCT & $\begin{array}{l}\text { No } \\
\text { Yes }\end{array}$ & $\begin{array}{l}550 \\
11,438\end{array}$ & $\begin{array}{l}1286 \\
40,145\end{array}$ & $\begin{array}{l}\mathrm{I} \\
\mathrm{I} .62(1.45,1.8 \mathrm{I})\end{array}$ & $\begin{array}{l}\text { I } \\
1.29(1.12,1.48)^{*}\end{array}$ \\
\hline Community level education & $\begin{array}{l}\text { Low } \\
\text { High }\end{array}$ & $\begin{array}{l}6849 \\
5139\end{array}$ & $\begin{array}{l}18,666 \\
22,766\end{array}$ & $\begin{array}{l}\text { I } \\
2.92(2.54,3.36)\end{array}$ & I.88(I.58, 2.25)* \\
\hline
\end{tabular}

Note: ${ }^{*}$-value $\leq 0.05$. 
women who initiated sex before the age of 20 years. This was supported by the study conducted in sub-Saharan Africa. ${ }^{31}$ This might be explained as early age at first sexual intercourse is associated with a higher risk of acquiring different sexually transmitted disease and risky sexually behavior that may leads to higher risk for HIV infection, which indirectly enforce them to know their HIV status. ${ }^{32}$

\section{Strength and Limitation of the Study}

First, the study was based on weighted nationally representative data from 11 eastern African countries with large sample size. Also, we used the multilevel analysis to accommodate the hierarchical nature of the DHS data to get reliable standard error and estimate. Moreover, since it is based on the national survey data the study has the potential to give insight for policy-makers and program planners to design appropriate intervention strategies both at national and regional levels. The potential limitation of the study was that the DHS survey was based on respondents' self-report, this might have the possibility of recall bias. Besides, since this study was based on cross-sectional ly conducted DHS data, it is difficult to show the temporal relationship between HIV testing and independent variables.

\section{Conclusion}

The prevalence of HIV testing among pregnant women was higher in eastern Africa compared with the report from different studies. Different socioeconomic and behavioral characteristics were associated with HIV testing. Age of respondent, wealth status, educational status, marital status, awareness about MTCT of HIV/AIDS, HIV knowledge, stigma indicator, risky sexual behavior, women who visit a health facility, multiple sexual partnership, age at first sex and employment status were the individual-level factors that were significantly associated with HIV testing among pregnant women in eastern Africa. While residence and community-level education were the community-level factors that affect HIV testing among pregnant women. Therefore, giving special attention for those group of women who are at higher risks of not having HIV testing such as those from rural areas and uneducated women could increase HIV/AIDS testing.

\section{Abbreviations}

CI, confidence interval; CSA, Central Statistical Agency; DHS, Demographic Health Survey; EA, Enumeration Area; ICC, intraclass correlation coefficient; HIV, human immune deficiency virus; AIDS, acquired immune deficiency syndrome; LLR, likelihood Ratio; MTCT, motherto-child transmission; WHO, World Health Organization; MOR, median odds ratio.

\section{Data Sharing Statement}

All result based data are with in the manuscript and the data sets are available online and any one can access it from www.measuredhs.com.

\section{Ethical Approval and Consent to Participate}

Since the study was a secondary data analysis of publically available survey data from the MEASURE DHS program, ethical approval and participant consent were not necessary. We requested DHS Program and permission was granted to download and use the data for this study from http://www.dhsprogram.com. The Institution Review Board approved procedures for DHS public-use datasets do not in any way allow respondents, households, or sample communities to be identified. There are no names of individuals or household addresses in the data files.

\section{Acknowledgments}

We greatly acknowledge MEASURE DHS program for granting access to the Demographic and Health Surveys data.

\section{Author Contributions}

All authors made a significant contribution to the work reported, whether that is in the conception, study design, execution, acquisition of data, analysis and interpretation, or in all these areas; took part in drafting, revising, or critically reviewing the article; gave final approval of the version to be published; have agreed on the journal to which the article has been submitted; and agree to be accountable for all aspects of the work.

\section{Disclosure}

The authors declare that they have no conflicts of interest.

\section{References}

1. UNAIDS. Children and HIV Fact Sheet. Geneva, Switzerland: Joint United Nations Programme on HIV/AIDS; 2016. 
2. Tenthani L, Haas AD, Egger M, et al. HIV testing among pregnant women who attend antenatal care in Malawi. J Acquir Immune Defic Syndr. 2015;69(5):610. doi:10.1097/QAI.0000000000000669

3. Larsson G, Spångberg L, Lindgren S, Bohlin A-B. Screening for HIV in pregnant women: a study of maternal opinion. AIDS Care. 1990;2 (3):223-228. doi:10.1080/09540129008257734

4. Goldani MZ, Giugliani ERJ, Scanlon T, et al. Voluntary HIV counseling and testing during prenatal care in Brazil. Revista De Saúde Pública. 2003;37:552-558. doi:10.1590/S0034-89102003000500002

5. Meseret Y, Dulla D, Nega B. Prevalence and factors affecting disclosure of HIV status among pregnant women attending antenatal care in Addis Ababa public health centres: a cross sectional survey. Obstet Gynecol Int J. 2019;10(4):317-324.

6. Organization WH. Strategic Approaches to the Prevention of HIV Infection in Infants. WHO; 2003.

7. UNAIDS W. Statement on HIV Testing Services: New Opportunities and Ongoing Challenges. Unaids org; 2017.

8. Gourlay A, Wringe A, Todd J, et al. Factors associated with uptake of services to prevent mother-to-child transmission of HIV in a community cohort in rural Tanzania. Sex Transm Infect. 2015;91 (7):520-527. doi:10.1136/sextrans-2014-051907

9. Organization WH. HIV/AIDS Estimates and Projections in Ethiopia, 2011-2016. Geneva: WHO; 2011.

10. HIV/AIDS JUNPo. Miles to Go: Closing Gaps, Breaking Barriers, Righting Injustices. Geneva: UNAIDS; 2018.

11. HIV/AIDS JUNPo. Global HIV \& AIDS statistics-2018 fact sheet; 2018. Available from: http://www.unaids.org/en/resources/fact-sheet. Accessed August 8, 2018.

12. Coates TJ, Richter L, Caceres C. Behavioural strategies to reduce HIV transmission: how to make them work better. Lancet. 2008;372 (9639):669-684. doi:10.1016/S0140-6736(08)60886-7

13. Drew O, Patel R. HIV-early diagnosis: key to improved prognosis and the reduction of onward transmission. Clin Med (Northfield Il). 2011;11(4):358. doi:10.7861/clinmedicine.11-4-358

14. Dombrowski JC, Harrington RD, Golden MR. Evidence for the long-term stability of HIV transmission-associated sexual behavior following HIV diagnosis. Sex Transm Dis. 2013;40(1):41. doi:10.1097/OLQ.0b013e3182753327

15. Steward WT, Remien RH, Higgins JA, et al. Behavior change following diagnosis with acute/early HIV infection - a move to serosorting with other HIV-infected individuals. The NIMH Multisite Acute HIV Infection Study: III. AIDS Behav. 2009;13(6):1054-1060. doi:10.1007/s10461-009-9582-6

16. Ejigu Y, Tadesse B, Paxton WA. HIV testing during pregnancy for prevention of mother-to-child transmission of HIV in Ethiopia. PLoS One. 2018;13(8):e0201886. doi:10.1371/journal.pone.0201886

17. Ejigu Y, Magnus JH, Sundby J, Magnus M. Health outcomes of asymptomatic HIV-infected pregnant women initiating antiretroviral therapy at different baseline CD4 counts in Ethiopia. Int J Infect Dis. 2019;82:89-95. doi:10.1016/j.ijid.2019.02.019

18. Asaolu IO, Gunn JK, Center KE, Koss MP, Iwelunmor JI, Ehiri JE. Predictors of HIV testing among youth in sub-Saharan Africa: a cross-sectional study. PLoS One. 2016;11(10):e0164052. doi:10.1371/journal.pone.0164052
19. MOH. Guidelines for HIV Counselling and Testing in Ethiopia. Ministry of Health Addis Ababa; 2007.

20. Ajayi A, Awopegba O, Owolabi E, Ajala A. Coverage of HIV testing among pregnant women in Nigeria: progress, challenges and opportunities. J Public Health (Bangkok). 2019.

21. Erena AN, Shen G, Lei P. Factors affecting HIV counselling and testing among Ethiopian women aged 15-49. BMC Infect Dis. 2019;19(1):1076. doi:10.1186/s12879-019-4701-0

22. Ajayi A, Awopegba O, Owolabi E, Ajala A. Coverage of HIV testing among pregnant women in Nigeria: progress, challenges and opportunities. J Public Health (Oxford, England). 2019. doi:10.1093/pubmed/fdz152

23. Yaya S, Oladimeji O, Oladimeji KE, Bishwajit G. Prenatal care and uptake of HIV testing among pregnant women in Gambia: a cross-sectional study. BMC Public Health. 2020;20(1):485. doi:10.1186/s12889-020-08618-4

24. Pérez K, Blanch C, Casabona J, Almeda J, Coll O. Coverage of HIV testing among pregnant women in Catalonia, Spain: a comparison of self-reporting with medical records. Eur J Public Health. 2004;14 (3):261-266. doi:10.1093/eurpub/14.3.261

25. Bekele YA, Fekadu GA, Torpey K. Factors associated with HIV testing among young females; further analysis of the 2016 Ethiopian demographic and health survey data. PLoS One. 2020;15 (2):e0228783. doi:10.1371/journal.pone.0228783

26. Spasojevic N, Vasilj I, Hrabac B, Celik D. Rural-urban differences in health care quality assessment. Mater Sociomed. 2015;27(6):409. doi:10.5455/msm.2015.27.409-411

27. Mugabe D, Bhatt N, Carlucci JG, et al. Self-reported non-receipt of HIV test results: a silent barrier to HIV epidemic control in Mozambique. PLoS One. 2019;14(10):e0224102. doi:10.1371/journal.pone. 0224102

28. Khamisa N, Mokgobi M. Risky sexual behaviour and human immunodeficiency virus (HIV) and acquired immune deficiency syndrome (AIDS) among healthcare workers. South Afr J HIV Med. 2018;19(1). doi:10.4102/sajhivmed.v19i1.744

29. Paulin HN, Blevins M, Koethe JR, et al. HIV testing service awareness and service uptake among female heads of household in rural Mozambique: results from a province-wide survey. BMC Public Health. 2015;15(1):132. doi:10.1186/s12889-015-1388-z

30. Teklehaimanot HD, Teklehaimanot A, Yohannes M, Biratu D. Factors influencing the uptake of voluntary HIV counseling and testing in rural Ethiopia: a cross sectional study. BMC Public Health. 2016;16 (1):239. doi:10.1186/s12889-016-2918-z

31. Mandiwa C, Namondwe B. Uptake and correlates of HIV testing among men in Malawi: evidence from a national population-based household survey. BMC Health Serv Res. 2019;19(1):203. doi:10.1186/s12913-019-4031-3

32. Ghebremichael M, Larsen U, Paintsil E. Association of age at first sex with HIV-1, HSV-2, and other sexual transmitted infections among women in northern Tanzania. Sex Transm Dis. 2009;36 (9):570-576. doi:10.1097/OLQ.0b013e3181a866b8
HIV/AIDS - Research and Palliative Care is an international, peerreviewed open-access journal focusing on advances in research in HIV, its clinical progression and management options including antiviral treatment, palliative care and public healthcare policies to control viral spread. The manuscript management system is completely online and includes a very quick and fair peer-review system, which is all easy to use. Visit http://www.dovepress.com/testimonials.php to read real quotes from published authors. 